\title{
Information Asymmetry as a Barrier in Upgrading the Position of Local Producers in the Global Value Chain-Evidence from the Apple Sector in Poland
}

\author{
Michał Pietrzak ${ }^{1}$, Aleksandra Chlebicka ${ }^{1}$, Paweł Kraciński ${ }^{2}$ and \\ Agata Malak-Rawlikowska ${ }^{1, *(\mathbb{D})}$ \\ 1 Department of Economics and Organization of Enterprises, Institute of Economics and Finance, \\ Warsaw University of Life Sciences-SGGW, 02-787 Warsaw, Poland; michal_pietrzak@sggw.edu.pl (M.P.); \\ aleksandra_chlebicka@sggw.edu.pl (A.C.) \\ 2 Department of Economics of Agricultural and Horticultural Holdings, Institute of Agricultural and Food \\ Economics IERiGŻ-PIB, 00-002 Warsaw, Poland; pawel.kracinski@ierigz.waw.pl \\ * Correspondence: agata_malak_rawlikowska@sggw.edu.pl; Tel.: +48-225-934-220
}

Received: 22 July 2020; Accepted: 20 September 2020; Published: 23 September 2020

\begin{abstract}
The typical approach in the business strand of literature on inter-organisational forms of cooperation is based on the Porter's value chain model or on the body of literature related to the supply chain. However, there is extended research on value chains based on a different theoretical tradition, rooted in world-systems theory and commodity chain concepts, which recently tend to merge under the umbrella of the Global Value Chain (GVC). We use this eclectic approach as a theoretical framework to investigate the issue of informational asymmetries considered as a barrier in upgrading the position of local producers in the GVC by enhancing quality. As an empirical illustration, we use the Polish apple sector. Poland is one of the largest apple producers in the world with a strong export orientation and linkages with the global value chain. The study provides an insight into the barriers of upgrading the position in GVC and ways to overcome them. Responsibility for the final quality offered for the end-user is strongly dispersed across many actors in the chain, while interrelations between them are plagued by the information asymmetry problem. Therefore, the upstream transmission of end-user quality expectations within the chain fails due to the lack of orchestrating incentives and causes the misbehaviour in conducting different activities in the chain. Thus, attempts to upgrade the position of Polish apple growers in the GVC should be focused on overcoming information asymmetries. Mechanisms such as branding, standardisation and certification seem to be promising ways forward.
\end{abstract}

Keywords: value chain; global value chain; GVC; upgrading; information asymmetry; bargaining power; apples; world-systems theory; commodity chains; Poland

\section{Introduction}

The value chain concept is widely used as a theoretical underpinning in studies related to agriculture that aim at deeper understanding of food systems, explaining their conduct, predicting their evolution and strengthening the farmers' position. The value chain concept has a multithreaded origin. On the one hand, it refers to the body of literature on the value chain and value system initiated by Porter [1] (1998); on the other hand-to the idea of Wallerstein's world-systems [2-4] and the Global Commodity Chain (GCC). GCC since 2000 evolved into Global Value Chain (GVC)—an eclectic approach, which considers Porter's "value" notion. GVC is the basis of our deliberations.

According to Ruben et al. [5] (2007), in developing countries, there exist three distinct agri-food sub-systems (here understood as chains): A, based on micro-producers delivering to local, low income markets; B, based mainly on small- and medium-size farmers, delivering mainly to local, middle-high 
income markets; and the $C$ system, which is an export-oriented chain. In order to have access to attractive markets, all members of the chain should have relevant information and should be able to comply with demands of the value chain's final consumers. Typically, information is imperfect and its stocks vary among different agents in the chain. Such a situation is defined as information asymmetry of the parties. Information asymmetry thus creates one of the most important constraints in these chains and relates strongly to the issue of quality.

One of the examples of the typical problem of information asymmetry in the global value chain is the case of the apple chain. Poland is the biggest apple producer in the European Union (EU) and one of the largest producers in the world. With an average annual production of 3.3 million tonnes, it occupies the third place after China and the USA. Poland's share in world production is nearly $4 \%$, but its share in global exports reaches $11 \%$ of volume, which indicates the country's strong export orientation and its connection to the global value chain. While having a strong position in the trade volume, its share in export value is only $4 \%$. However, in countries competing with Poland in the EU, such as Italy or France, or outside Europe-the USA, Chile and even China, the share in export value is higher than in export volume. Consequently, it can be concluded that Poland's position in the global value chain is based on price competition and not on quality. The ability to offer high quality apple is a challenge. Apple is a nexus of attributes, many of which are experience, or even credence, attributes. Such a situation creates information asymmetries between exchange parties, while a better-informed party has an incentive to not care about quality and still not be punished for such misbehaviour. The picture gets even worse when one takes into account the systemic relations and dispersion of influence responsibility for any particular quality attribute within the whole inter-organisational chain.

The passage of time may only exacerbate the problem, as competing countries like Ukraine, Russia, Moldova, which are willing to take positions in the low-grade apples segment, are growing in position. This threatens Poland with a loss of its position in the global value chain and, as a consequence, a drop in income and even bankruptcies of many farms.

The problem of farmers' position in the value chain is a vastly debated topic (see, e.g., [6-10]). Especially in Central and Eastern Europe, which experienced almost fifty years of communist dictatorship, it has been frequently stressed that farmers are usually poorly capitalised and thus have limited bargaining power [8]. While the existing literature has substantially improved our knowledge about the functioning of the agri-food supply chain, the problem of information asymmetry has rarely been discussed in the context of farmers' position in the value chain. Thus, the purpose of the paper is twofold. First, we present the case study of the Polish apple growers and the challenges they faced in the local value chain, as well as in trying to insert their activities into the global value chain (particularly after Russia's ban on import imposed in 2014). Subsequently, we discuss the potential of upgrading their position and analyse the constraints to be overcome, with an emphasis on the information asymmetry problem. We believe that both the empirical illustration and its theoretical explanation might be interesting from the point of view of emerging and developing economies. Secondly, we present the development of a multifaceted concept of the Global Value Chain (with a special focus on the agri-food chains), which in our opinion creates a useful general framework to analyse the position of farmers from peripheral and semi-peripheral countries against globalization forces.

Our study has an explorative character. The empirical part of the paper has a mainly qualitative and descriptive nature. However, in our opinion, it is justifiable at this stage of research on the topic. To the best of our knowledge, this paper represents the first attempt to describe the apple sector in Poland in the context of information asymmetry and from value chain perspectives, based on the GVC framework.

\section{Theoretical Approach to Understanding and Interpreting the 'Value Chain' Concept}

Generally speaking, the term 'value chain' (VC) is understood as a full range of processes (activities) associated with the delivery of a good (product or service) - from its research and development through the supply of production factors, manufacture, trade to final consumption [1,11-13]. The value chain 
explained in this way can be viewed from many perspectives. Generally speaking, there are two main strands of literature regarding VC: business and management perspective and socio-economic approach.

\subsection{Business and Management Strand}

In 1980, a group of consultants from McKinsey\&Co. developed an internal document entitled "Competitive cost analysis", presenting the methodology related to determining competitive advantage based on costs. This study introduced the concept of a 'business system'. The same year, McKinsey Quarterly published an article [14], showing the business system in the broader context of creating company strategy. The idea of a business system was based on a sequential scheme of processes (technology, product design, production, marketing, distribution, service) carried out in an enterprise to deliver products or services to the market. Each link of this system is an area of strategic management decisions concerning the way of doing business and a potential source of competitive advantage [12].

Five years later, Porter presented the concept of a 'value chain' with clear reference to the previous ideas of McKinsey\&Co consultants. However, Porter's notion bears traces of originality. It divides the processes conducted in the company into two categories: primary activities (relating to the physical manufacture of the product, its sale and transfer to a purchaser and after-sales support) and supporting activities whose role is to support basic activities by providing purchased inputs, technologies, human resources and other functions supporting the operation of the whole enterprise [1].

Original and key to Porter's concept is also the notion of value. It is understood as the amount that purchasers are willing to pay for the product/service. The essence of the value chain, as a strategic management tool, is to analyse particular activities of a given firm in terms of their relative cost position and the role they can play in building unique benefits for the customer. It should be noted that Porter was aware that a firm's value chain was integrated into a wider process stream, which he described as a 'value system' [1].

Within the framework of the business-management perspective, a complementary approach was developed in the body of literature rooted in logistics. The supply chain concept emerged in the 1970s with a focus on the integration of logistics operations within companies to reduce costs $[15,16]$. Gradually, the supply chain began to be thought of in a broader context, i.e., going beyond the borders of a single company [15,17-19]. Integration and matching lie at the heart of the supply chain concept $[20,21]$, including the integration and adaptation of cooperating companies. In this broader sense, the term 'supply chain' was first used in the early 1980s by Oliver and Weber [22] (1982). Initially, an integrated approach to supply chain management (SCM) focused on minimising costs $[15,19]$. The central issue for the supply chain concept is to move away from treating its links separately and looking at them in an integrated, systemic way. By integrating the links in the supply chain, it is also possible to achieve other benefits beyond cost reduction. Gradually, as the concept of supply chain management developed, the focus on costs was replaced by the concept of customer value [15].

\subsection{Socio-Economic Strand}

A separate research stream is an approach that can be described in economic and sociological terms. The concept of filière (thread, chain), developed in the 1960s by French industrial economics researchers specialising in agriculture and agribusiness, played a pioneering, though largely forgotten, role in this $[23,24]$. Filière was developed as an analytical approach to examining price formation at different stages of physical transformation (production, storage, transport, processing), from raw material to final product [23]. A specific feature of filière was its empirical orientation [24] focusing on meso-economic relations, i.e., vertical ties between entities [25]. Since the late 1980s, there has been a decline in interest in the filière concept [24].

In parallel, since the late 1970s the concept of the commodity chain developed on the basis of the world-systems theory, began to gain popularity. The American sociologist, historian and economist Wallerstein, who also draws extensively on the work of the French historian Braudel, is the author of the theory of world-systems. The essence of Wallerstein's theory is not only the long horizon of 
analysis but also the emphasis on the need to go beyond the national perspective, to flows of goods that make up the world-systems [2,26].

The world-system should be treated not so much as a unit covering the whole globe, but rather as a system that creates a kind of universe for its participants, which can be relatively small in geographical terms. Historically, there were many separate world-systems (amongst others: Europe, the Islamic world, India, China, Japan). The modern era witnessed the territorial expansion of the capitalistic system, which nowadays has absorbed the whole globe into its universe. Economic flows, due to unequal exchange, affect the polarisation of the system - the creation of core and peripheral countries. In core areas, innovations are created and high-value added goods are produced. Peripheral countries are a source of raw materials and a reservoir of cheap labour force. It is also possible to distinguish areas of the semi-periphery, which can mediate between the core and the periphery. The key to the concept of world-systems is the observation that countries, through political action, can try to improve their position $[2,26]$

This idea was then developed by the concept of 'chains of merchandising' [2]. In subsequent publications of Wallerstein, developed together with Hopkins [3,4,27], a modified term 'commodity chain' appears. Commodity chains contain combinations of central activities allowing for high profit rates and peripheral activities generating low profits. However, it can be observed that the mix of activities carried out in a particular country may change over time. Therefore, it is advisable to define the objectives of the national development programme as an increase of the following ratio: the core processes vs. peripheral activities carried out in a given country [28]. This idea leads us directly to the concept of upgrading, i.e., improving the position in the chain [29], which is related to the Global Commodity Chains (GCC) concept developed by Gereffi et al. [24,30]. GCC has grown out of the literature stream of commodity chains discussed above, though as it developed, it has moved away from its roots understood as a theory of world-systems.

\subsection{Towards Synthesis of the 'Value Chain' Concept}

The period of development of the GCC concept occurred in the 1990s. After this decade, Gereffi et al. considered it necessary to modify their concept so significantly that it would be emphasised by the change of name-Global Value Chain (GVC) [31]. The change of notions from Global Commodity Chain to Global Value Chain reflects Porter's concept, with his idea of adding value through chain activities and financial performance as a measure of competitive advantage [31]. In this way, GVC can be regarded as an eclectic construct combining the achievements of two strands of research on vertical inter-organisational links: the business-management strand and the socio-economic one. Authors of this paper acknowledge the great value in the eclectic nature of the GVC concept. While continuing the socio-economic strand, it is also trying to integrate the achievements of other streams-including Porter's value chain and supply chain management [32]. The Global Value Chains concept could shed light on inter-organisational cooperation on the global scale and therefore could be seen as an extension in comparison to the business-management-oriented approach. All these features of the GVC concept fit well with the research approach of our paper.

\section{Agri-Food Value Chains in Developing Countries and Information Asymmetry Challenge}

The value chain concept is commonly used as a theoretical background in studies related to agriculture that aim at deeper understanding of food systems, explaining their conduct and predicting their evolution and-last but not least—in strengthening the farmers' position (particularly regarding farmers from developing countries). According to Ruben et al. [5], in developing countries, there exist three distinct agri-food sub-systems (or agri-food chains from our perspective) - A, B, C - that refer to different quality and safety demands, internationalization and market differentiation.

The A system is based on numerous micro producers conducting traditional production forms. They typically aim at local, low-income markets with basic food products. Sometimes these chains could also be connected to the international system as a source of supply for low-end markets. Commonly, 
type-A chains deliver a high proportion of the volume of a given agricultural product, while having a relatively low share in the value. The B system is based mainly on small- and medium-size farmers, often organized in cooperatives and/or governed by subcontracting arrangements. Micro producers are also present as suppliers in this segment; however, they play only the buffer role in balancing the $B$ system. Type-B chains aim at local, middle-high income markets, often in the emerging supermarket sector. In this last case, producers increasingly comply with quality and safety standards. In comparison to the A system, B system typically produces less in volume but has a higher share in value. The $\mathrm{C}$ system is just the export-oriented chain. While type-A chains are sometimes involved in export, aiming at low-end markets, the C-system producers aim at high value-added markets. Such markets are highly selective; therefore, products that do not meet high quality standards are placed on the national market. Type-C chains typically consist of relatively fewer but more integrated producers. They are mainly large producers, but small-medium producers are also present in $\mathrm{C}$ chains through intermediaries. In comparison with the A and B systems, the output of $C$ systems is small in volume but is described by a higher value added [33]. The share in value depends mostly on the farmers' expertise, access to know-how and capital, and is usually linked to farm size.

Trienekens [33] proposed an analytical approach for studies of agri-food value chains in developing countries, which we present in a slightly modified form in Figure 1. This framework consists of three components: main barriers for farmers upgrading, chain structure defined by input-output flows, and upgrading options. We use this framework in the further analysis. Starting with the barriers for upgrading we can distinguish the following constraints [33]:

- lack or weaknesses of relevant institutions,

- deficiencies in physical infrastructure and resources,

- market access and knowledge as a prerequisite to access the market.

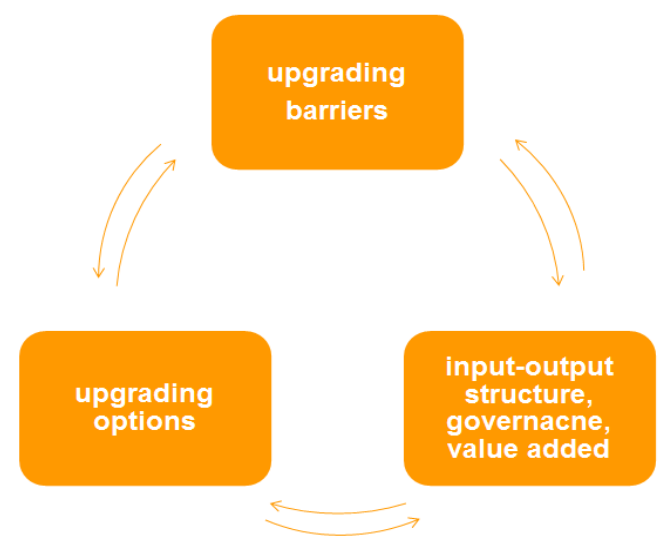

Figure 1. Framework of agri-food value chain study; Source: elaboration based on ([33] Trienekens 2011, p. 60).

Market access depends not only on technological competences and abilities but also on market information and orientation. Regarding Grunert et al. ([34], pp. 428-429) "market orientation is commonly defined as the extent to which an actor in the marketplace uses knowledge about the market, especially about customers, as a basis for decision-making on what to produce, how to produce it, and how to market it", which is a condition to create superior value for the customer. Traditionally, market orientation has been viewed from a dyadic perspective (company vs. customers). However, there has been a growing literature looking at market orientation from a value chain perspective [35-40]. This approach has emphasised the inter-organizational vertical relationships; thus, the extended definition of market orientation could be: "chain members' generation of intelligence pertaining to current and future end-user needs, dissemination of this intelligence across chain members, and chain wide responsiveness to it." ([27], p. 430). 
Consequently, the market orientation of one actor in the value chain is influenced by the degree of market orientation of other chains' actors [41]. Thus, the ability of the whole chain to create value for the final consumers will be related to how the actors at various stages of the chain together perform the task of generating intelligence on end-consumer needs and how they use it to guide their processes [34]. This in turn implies that to have access to attractive markets, members of the chain up to the primary producer should have relevant information and should be able to comply with the demands of the value chain's final consumers. Therefore, except for commodities, the market orientation of actors at multiple stages of the chain is the prerequisite for value creation [42]. "The further upstream market information on product quality and other product attributes requested penetrates the value chain, the more heterogeneous markets can in principle be served, assuming that producers can comply with market demands" ([33], p. 55).

This reasoning brings us to the issue of information asymmetry, which in our opinion creates one of the most important constraints in the apple chain in Poland. By overcoming the asymmetric information barrier, Polish growers may gain access to more attractive buyers in the global chain, and thus capture more value.

In opposition to the standard assumption of neoclassical economics, the information available to the market partners is neither excellent nor costless. Typically, information is imperfect and its stocks vary among different agents. Such a situation is defined as an information asymmetry of the parties. People and firms can take action to overcome the difference, and to obtain information, which is costly [43]. Information asymmetry offers an advantage to the better-informed party. This issue creates problems in market relations, also related to quality assurance within the value chain. It is reasonable to make a behavioural assumption that people are susceptible to opportunism, which is defined by Williamson ([44], p. 47) as a "self-interest seeking with guile". Therefore, the better-informed party (e.g., producer) can use its advantage to sell a product of inferior quality-a lemon. Furthermore, the structure of incentives could be shaped in such a manner that a better-informed supplier could economise on costs by lowering product quality without being punished. This is common when the attributes of products or services are not easy to verify ex ante or even at all.

Nelson [45] differentiated between two kinds of attributes of any good: search attributes and experience attributes. Search attributes are those which buyers could assess before buying. By all means, it could be sometimes costly to acquire information about those attributes. However, knowledge about them is possible to be gained by searching before the buying act. Such activities generate search costs. For example, one could easily assess the size, shape, colour and general appearance of apples. Furthermore, it is not costly to gain information on the taste or other traits of any variety (e.g., Gala) or a brand name (e.g., Pink Lady). However, it is not possible to assess the real taste and aroma, texture and crispness, etc., of any particular apple before eating it. Experience attributes are those which buyers could assess only after buying — by using a particular product/service. Tirole [46] states that "the main issues in regard to such goods [goods with experience attributes] are whether there are incentives for firms to supply quality" ([46], p. 95).

Darby and Karni [47] added a third category to Nelson's classification, i.e., credence attributes. These are attributes valuable for a buyer, though he/she cannot evaluate them by normal use. Typical examples relate to medical treatment, business consulting, etc. Thus, we draw attention to our case-consider the issue of pesticide residues on apples that can be evaluated only by special laboratory tests.

\section{Structure of the Polish Apple Value Chain in the Global Context}

Apples are one of the most widely cultivated tree fruit and the third most internationally traded fruit following bananas and grapes. Their popularity is global-they are consumed worldwide in greater quantities than any other temperate region tree fruit [48]. Apples may be consumed as fresh (labelled dessert or table apples) but the production is also converted into processed apple products, such as apple juice concentrate (AJC), juice, ciders, jams, purees, sauces, etc. 
Apple consumption continues to grow at a moderate pace (about $+3 \%$ annually) following rising incomes and population growth as well as programmes promoting balanced nutrition [49]. However, the global consumption has changed drastically over the last 10 years. In the apple producing countries of Western Europe and Northern America, consumption has clearly decreased. On the other hand, consumption in the southern hemisphere has grown. Even so, apples are commonly the most consumed fruit in Europe with an average annual consumption of $15 \mathrm{~kg}$ per person [50].

In recent years, dessert apple production in the world amounted to about 84.5 million tonnes per year [49]. The largest global markets for fresh apples are China, the European Union and the United States. The Chinese apple industry dynamically increased its share in global production, now amounting to 45 percent. The EU and the United States were the world's second and third largest apple producers, respectively. Poland is the largest apple producer in the European Union and the third in the world (after China and the USA). Other large producers include Iran, Turkey, Russia, India and Chile [50]. Harvest in particular years fluctuates due to the variability of yielding which is most often caused by weather conditions (frosts, drought, hailstorms). Poland's share in the global output, with an average annual harvest of 3.3 million tonnes (2016-2018) is about four percent, and 35 percent in the EU. In addition, Poland is the first in Europe and the second (12 percent share) in the world producer of apple juice concentrate (AJC).

The world's largest apple producers are also its primary apple consumers and traders. The four largest exporters (China, the EU, Chile and the United States) accounted for 70 percent of global trade in 2018. At the same time, the share of Poland in the volume of global apple exports amounted to $11 \%$. However, when we take into consideration the export value, it turns out that Poland's share was only $4 \%$. The reason for such an unfavourable relation is that the prices of apples exported from Poland were among the lowest in the group of the ten largest world exporters.

The Russian import embargo introduced in 2014 dramatically changed the trade situation for apple producers in the EU, particularly in Poland. Unexpectedly, Poland lost the largest export market for its apples. Indeed, in 2013, Poland exported 600 thousand tonnes of apples to Russia, about half of its total fresh apple exports [51]. Problems with the sale of apples on foreign markets, combined with a period of unprecedented harvest, had a strong negative impact on the price level of apples and consequently on the income situation of producers. The crisis in the industry has revealed serious problems that have been growing for many years. In search of primary causes and solutions to these problems, in the next section, we take a closer look at the input-output structure of the apple value chain.

To begin a discussion on the apple value chain structure, we start by presenting a simplified scheme of processes (activities) in which Polish growers participate (Figure 2).

As apple growers remain at the centre of our interest, we commence by analysing issues related to apple production. During the last decade (2010-2019), the average total apple-growing area in Poland was about 177 thousand ha. The apple harvest shows an upward trend with the average annual growth rate of about five percent for the last decade. The growth in total output is primarily the result of the increasing yields of apples following the systematic modernisation of orchards. However, apple production in Poland remains very fragmented [52]—see Figure 3. According to official statistical data, there are about 109 thousand farms with apple orchards. We can distinguish four groups of orchards that clearly differ in terms of size, productivity and role in the market.

The first group includes the smallest (up to $1 \mathrm{ha}$ ) and at the same time the most numerous (about 77 thousand) farms that have practically no significance in terms of commercial activities. These are basically semi-subsistence home or wild abandoned orchards (Figure 3). The second group is composed of nearly 20 thousand producers owning $1-5$ ha orchards. These holdings do not possess adequate infrastructure and most producers do not have sufficient expertise in the production of high quality dessert apples, and the average yield is about $16 \mathrm{t} / \mathrm{ha}$. The total harvest is about 0.8 million $\mathrm{t}$ and the output is mainly directed to AJC processing companies via brokers (Figure 2, arrows 5 and 7). Prices received by growers hardly cover production costs, and more recently, this type of production is no longer profitable due to rising costs of apple picking. The third group encompasses 
about 9 thousand growers owning holdings of size ranging from 5 to 10 ha with average yield of about $22 \mathrm{t} / \mathrm{ha}$. The output generated by these producers is about $1.2 \mathrm{Mt}$ and it is largely sold to AJC processing companies (Figure 2, arrows 5 and 7). However, some producers representing this group manage to get an appropriate level of quality and they market about $0.3-0.4 \mathrm{Mt}$ as dessert apples (Figure 2, arrows 6, 11 and 13).

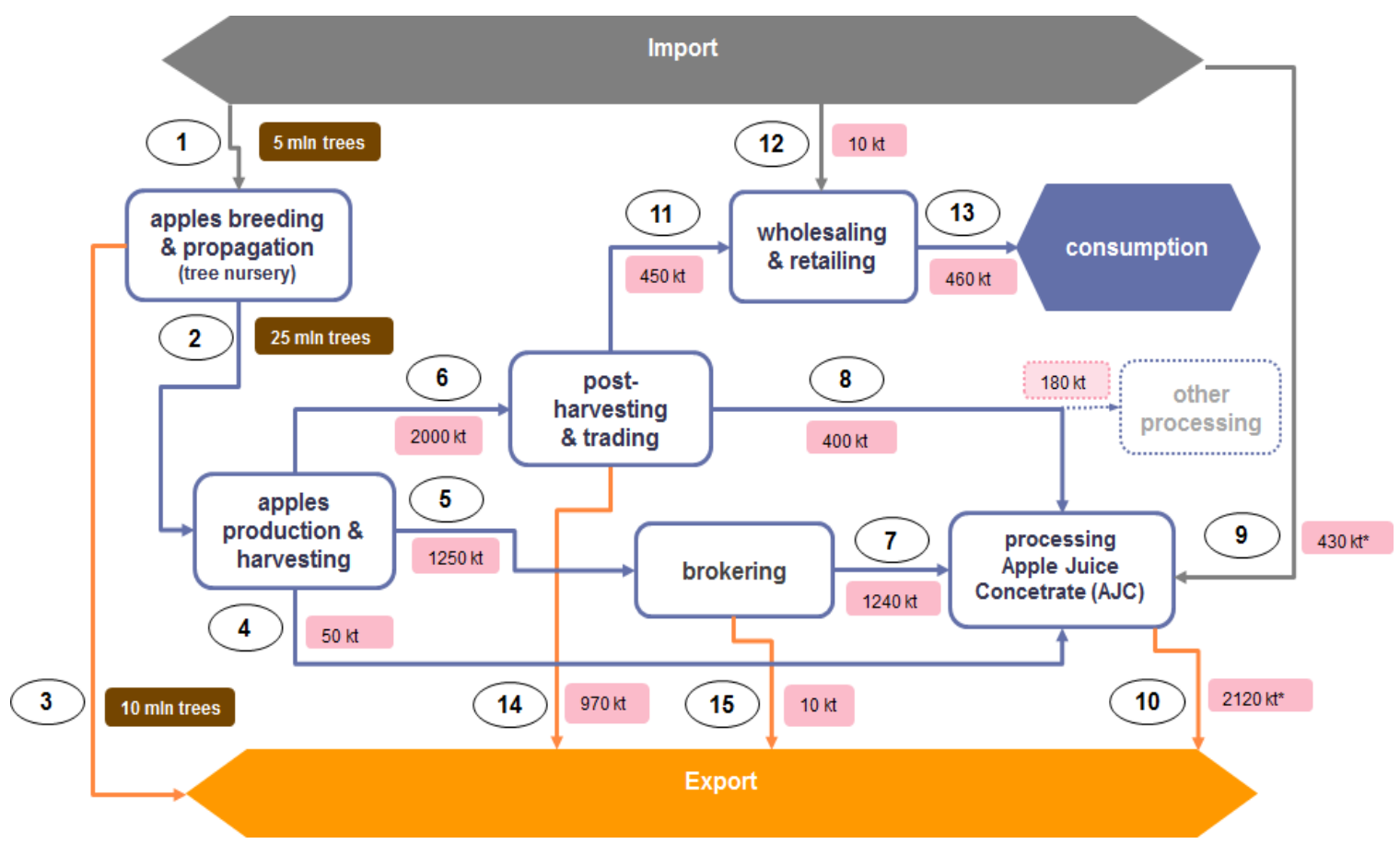

Figure 2. Input-output structure (based on activities) of the apple value chain in Poland; Caution: the structure is simplified-juices other than apple juice concentrate (AJC), as well as other processed products (purees, jams, ciders, etc.) responsible for about $180 \mathrm{kt}$ of fresh apples are not included in the detailed structure of the flows and are only noted on the graph (dotted lines); blue arrows denotes internal flows, grey arrows-inflows from import, orange arrows-exported outflows; pink frames-volumes of the flows in thousands of tonnes of apples; numbers marked by $\mathrm{kt}^{*}$ denotes raw apples equivalent of AJC; Source: own estimations.

w share in \# of farms $\quad$ share in area share in marketed output

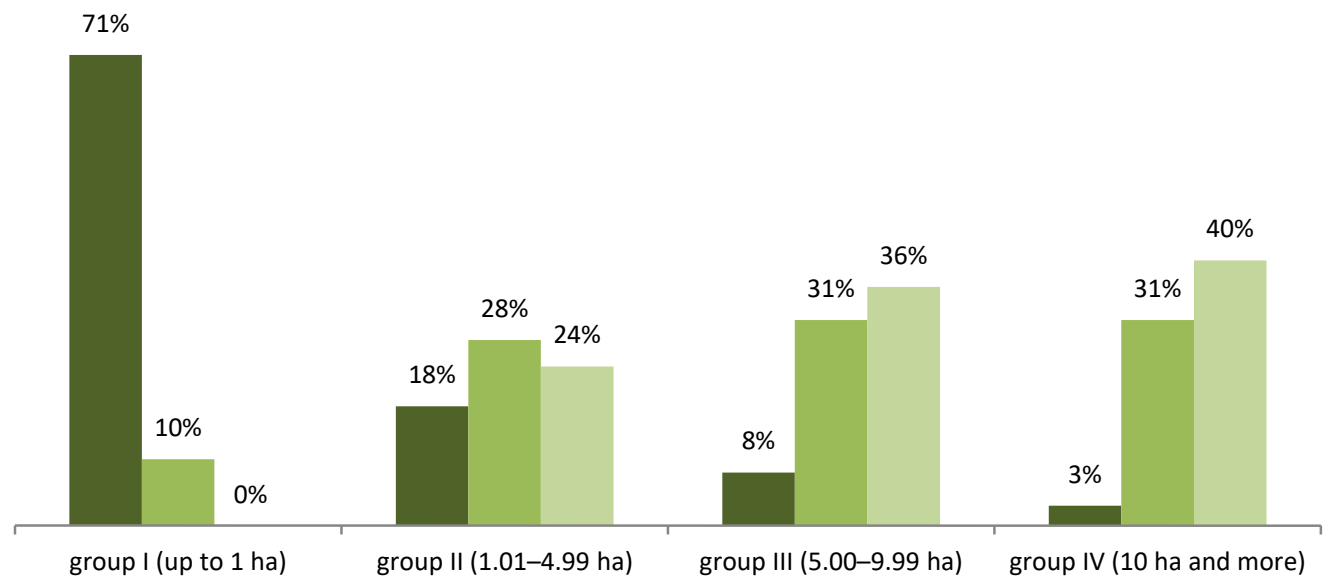

Figure 3. Structure of apple orchards in Poland in 2018; Source: own estimates based on GUS [53]. 
In the fourth group, there are orchards with higher productivity levels. They represent about 30 percent of the total growing area and in this case average yields are around $24 \mathrm{t} / \mathrm{ha}$, though these could range even up to $50 \mathrm{t} / \mathrm{ha}$. It is estimated that the outcome generated by these orchards is about 1.3 million $t$, including around 1 million $t$ of dessert apples of good quality and marketable varieties. There are about 3.3 thousand specialised producers in this group, with a high level of expertise and entrepreneurship. All these farms have the necessary technical infrastructure, and most of them are equipped with cold stores under controlled atmosphere. A significant proportion of producers in this group belong to producer organisations (POs). The apples grown in these orchards are mainly exported (Figure 2, arrows 6 and 14) or eventually sold at national market (Figure 2, arrows 6, 11 and 13). Due to natural quality fluctuation, about $30 \%$ of the output is sold to AJC processing (Figure 2, arrows 4 or 6 and 8 or 5 and 7 ).

If we juxtapose the classification of apple-growing farms (Figure 3) with Ruben et al.'s [5] typology covering the three types of chain discussed above, we may notice an interesting parallel. It turns out that, by and large, growers from the second and (in most cases) the third group participate in A system, producers partially from the third and the fourth group correspond with the $\mathrm{B}$ chain, and producers from the fourth group participate in the $C$ system. Growers from the second and the third group (in the majority) aim at low-end market represented in this sector by AJC processors. AJC from Poland reaches international markets as the cheap raw material for other products (mainly drinking juices). The best growers from the third group and some producers from the fourth group's aim at medium-high end local markets are represented in this case by the national market for dessert apples. A substantial part of growers from the fourth group aim at the high end international market. What is striking is the position of the first group. While representing more than two-thirds of growers and one out of every ten hectares under apple orchards, this group plays no particular role in the market. This could probably be specific for the highest developed among developing countries. As a consequence of sector development, those farmers not only failed in their attempts to upgrade their position in the chain, but actually experienced downgrading and were crowded out from the marketplace. What seems to be different in Poland regarding Ruben et al.'s [5] model is also the role of cooperatives/POs. They not only play a role in conducting post-harvesting and trading activities while supplying national markets, but also are important actors in exporting dessert apples.

In addition to fragmented production, the structure of apple varieties tends to be unfavourable. The most popular varieties grown in Poland are Idared (19\% share) and Champion (12\%), followed by Jonagold, Ligol (cultivar created in Poland) and Gloster (each about $8 \%$ share) [53]. Unlike in Poland, production in the top apple producing countries is dominated by Gala, Red Delicious, Golden Delicious and Fuji [54]. The trees of Gala, Golden Delicious and Red Delicious are usually imported from Western European nurseries (Figure 2, arrow 1). However, the vast majority of seedlings are still purchased domestically. About 25-30 million apple tree seedlings are produced in Poland including the illegal propagation by fruit growers and nurseries that may amount to about 5 million units per year. In the case of illegal multiplication, growers cannot be sure of the variety, the rootstock used or the health of the trees. Even so, less professional producers decide to buy such seedlings due to lower prices. Club varieties popular in the main apple producing countries are not currently grown in Poland.

The scope and place of the post-harvesting and trading activities depend strongly on the agri-food sub-system. Such activities are abandoned in the case of A system. In B and C systems, pre-sorting and storage are mostly carried out on farms, while pre-sale activities, i.e., sorting, grading and packing are conducted by producer organisations (POs) (Figure 2, arrow 6). POs have a 30 percent share in apple sales [55] and compared with similar entities in the EU, although they have relatively small economic power [56]. The main objective of Pos is to market the output delivered by its members, however, they also act as intermediaries purchasing apples from growers who are not members [55]. Concerning consumer transactions (sub-system B, Figure 2, arrow 13), the majority of fresh apples (65 percent) on the domestic market are delivered by large retailers. The most significant role in 
apple retailing is played by discount chains (over 25 percent share in sales) followed by super and hypermarkets [57]. Large retailers are supplied mostly by POs or the largest individual growers. About 30 percent of apples are sold through the marketplace, shops and street stalls. Produce sold through these channels is usually procured on wholesale markets, the smaller part coming directly from the producers. On wholesale markets, apple traders are mostly fruit growers themselves, usually owners of relatively small orchards (Figure 2, arrow 11).

The increase in the production of apples observed recently in Poland was not accompanied by a growth of consumption. On the contrary, domestic apple consumption showed a clear downward trend between 2005 and 2019. This decrease in apple consumption after Poland's accession to the EU was caused primarily by an increase in the consumption of citrus fruit. Some authors suggest that apples are perceived by many Polish consumers as less attractive compared with southern fruit [58]. It may also be linked to the fact that there are a lot of fresh apples of relatively low quality in the offer of retail stores.

A significant part of fresh produce is shipped to foreign markets (sub-system C; Figure 2, arrow 14). Most of Poland's fresh apple exports were traditionally destined for growing markets, mainly Russia and Ukraine. Unlike Italy and France, where more than 80 percent of fresh apple exports are shipped to other EU markets, before the embargo in 2014, only about 40 percent of Poland's exports were intra-EU. Before 2014, Russia was the main export destination for Polish apples absorbing half of the total export in terms of volume [59]. The growing demand of the Russian Federation influenced the increase in volume of export and production of apples in Poland [60].

The Russian ban on imports introduced in 2014 motivated Polish shippers (mainly POs and trading companies) to seek new markets in Europe, Southeast Asia, North Africa and the Middle East. New important export markets for Polish apples turned out to be Belarus, Kazakhstan, Germany and Romania. However, these markets remain small vis-à-vis Russia and so far have not been able to absorb the quantities previously sold to Russia [61]. Complicating efforts to offset the withdrawal of Russian demand is the fact that Polish orchards have been calibrated to serve Russian consumer preferences. About 20 percent of Polish production is of the Idared variety, apples easy to produce and liked in Russia but not popular in the rest of the world. Shippers also struggle with other quality issues in long-distance markets, as most varieties that are grown in Poland damage easily during transportation.

Due to the unsatisfactory quality of the part of dessert apples produced in small orchards, compounded by the problems resulting from the Russian embargo, over half of the total apple output in Poland is processed (Figure 2, arrows 4 or 5 and 7 or 6 and 8). Thus, apples sold for processing are largely apples that were originally intended to be sold as a dessert fruit. In years of high harvest, the share of processed apples reaches or even exceeds 60 percent. On the other hand, in low harvest seasons, the share of exports and domestic consumption in the distribution of apple supply increases. The main product made from apples in Poland is AJC, which accounts for about 90 percent of processed apples. Other categories of processed apple products comprise juice not from concentrate (NFC), cider, frozen apples and purees. There are about 60 companies involved in the processing of apples for juice, including 33 entities specialized in AJC manufacturing. Trade brokers act as an intermediary between growers and processing companies and their main function is to concentrate the supply of apples and to deliver large quantities using appropriate means of transport (Figure 2, arrows 5 and 7). These are usually small companies that trade with big processors manufacturing AJC. The surplus of dessert apples of insufficient quality for shippers combined with limited possibilities of domestic consumption creates a favourable situation for processors. Prices of apples for processing are typically about 3 times lower than of dessert apples and sometimes do not cover even the variable cost. In addition, note the extremely high fluctuations in prices received by growers in recent years:

- from 0.1 to $0.9 \mathrm{EUR} / \mathrm{kg}$ (on average about $0.3 \mathrm{EUR} / \mathrm{kg}$ ) in the case of dessert apples,

- from 0.02 to $0.25 \mathrm{EUR} / \mathrm{kg}$ (on average about $0.1 \mathrm{EUR} / \mathrm{kg}$ ) in the case of apples for further processing (differences between farm gate price and price paid for apples delivered to the plant in the minimal required volume create opportunities for brokering-compare Figure 2, arrows 5 and 7). 


\section{How Is the Information Asymmetry Manifested in the Apple Value Chain?}

The overview of the situation in the apple sector in Poland presented above leads to two important conclusions. Firstly, there is a high proportion of dessert apples in production which are processed due to their low quality. Secondly, there is a high degree of export dependence of this sector-in fact, only about 20 percent of domestic apple production is consumed in Poland. As for fresh apples, due to the need to replace Russia with other export markets, producers had to completely redefine their exporting strategies.

From the grower's point of view, the production of apples for processing is becoming less and less profitable. Growing good quality dessert apples, on the other hand, requires expertise and involves high production costs. However, in order for the investments in quality made by individual fruit growers to be economically justified, appropriate mechanisms are still needed to deal with the asymmetry of information in assessing the quality of fresh apples. It is to be expected that if the additional efforts made by producers to improve apple quality are not rewarded by the market (or by other governance mechanism), there will be no fundamental change in this respect. In the following section, we shall explain the problems related to the quality by focusing on the most important flows in the apple value chain, in which Polish producers participate. We take a closer look the risks associated with the information asymmetry affecting, in particular, the entities operating in the fresh apple value chain, where quality attributes cannot be easily standardised, as in the case of AJC for instance. Data for this section were collected through in-depth interviews with apple growers, CEOs of producer organisations, apple shippers, as well as relevant industry publications.

There exists a considerable body of literature on consumers' preferences regarding apple purchase and consumers' perceptions of apple quality. It is by now generally accepted that consumers purchase apples by considering intrinsic and extrinsic quality indicators [62-64]. The intrinsic attributes are those that cannot be altered without manipulating the nature of the product itself and include the product's physical appearance and organoleptic properties, whereas the extrinsic attributes are those that do not form the physical part of the product and are provided by the seller of the product $[64,65]$. Intrinsic attributes evaluated in consumer tests on apples usually relate to colour, size, smell, texture and flavour $[66,67]$. There have been numerous studies to investigate the most preferred attributes of apples. For instance, Bonany et al. [67] found that sweet taste and firmness were the most preferred value attributes in European countries. Moreover, studies have also revealed that extrinsic quality attributes like brand, origin and method of production are gaining importance while making a purchase decision (see, among others, [68-70]).

Noelke and Caswell [71] suggested that some of the intrinsic attributes can be further classified into attributes sought by the consumer prior to purchase, known as search attributes or attributes experienced during consumption, known as experience attributes. On the other hand, extrinsic indicators and cues usually fall under the category of search or credence attributes (unobservable through search or experience) [72-74]. Sexton [75] notes that there has been a significant increase in demand over recent decades for provision of a range of attributes in food products, many of which cannot be verified either ex ante or ex post by consumers. It turns out that important characteristics of apples are experience or credence in their nature. This means that relevant information on these attributes is difficult to ascertain directly by consumers at any stage of purchase and only to some extent after consumption of the fruit.

Nevertheless, the most important feature taken into account by customers when making a purchase, which is the freshness of the product, is no longer merely the result of the efforts and decisions of the producer, but also of other actors involved in supplying the product to the final consumer. Furthermore, as pointed out by Noelke and Caswell [71], a distinction between search, experience and credence attributes may vary for different actors in the value chain. For instance, what may be a credence attribute for consumers may be a search attribute for retailers or shippers as it is feasible for them to sample and test products. As noticed by Starbird and Amanor-Boadu [76], the food market is characterised by imperfect information with asymmetries allocated along the value chain. To illustrate 
issues discussed above, we present the matrix of influence and responsibilities in relation to shaping apple quality attributes within the value chain (Table 1). The first three columns represent the attributes of apple quality important from the consumer perspective. The following columns describe the level of influence and responsibilities related to shaping these quality attributes by different stages of the value chain. In the next part of the paper, we look more closely at the upstream value chain players facing problems with information asymmetry related to product quality.

Table 1. Apple quality attributes from the consumer perspective and location of efforts to shape them in the value chain.

\begin{tabular}{|c|c|c|c|c|c|c|}
\hline \multirow{2}{*}{\multicolumn{2}{|c|}{ Quality Attributes }} & \multirow[b]{2}{*}{ Type } & \multicolumn{4}{|c|}{ Stages (Activities) in the Value Chain } \\
\hline & & & $\begin{array}{l}\text { Breeding } \\
\text { and } \\
\text { Propagation }\end{array}$ & $\begin{array}{l}\text { Production } \\
\text { and } \\
\text { Harvesting }\end{array}$ & $\begin{array}{l}\text { Post-Harvesting } \\
\text { and Trading }\end{array}$ & $\begin{array}{c}\text { Wholesaling } \\
\text { and } \\
\text { Retailing }\end{array}$ \\
\hline \multirow{3}{*}{ 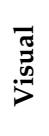 } & size & search & +++ & ++ & + & + \\
\hline & colour & search & +++ & ++ & + & + \\
\hline & $\begin{array}{c}\text { general appearance } \\
\text { (freshness) }\end{array}$ & search & 0 & +++ & +++ & +++ \\
\hline \multirow{3}{*}{ 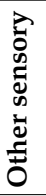 } & smell & search/experience & +++ & +++ & +++ & +++ \\
\hline & flavour & experience & +++ & +++ & ++ & ++ \\
\hline & texture & experience & +++ & ++ & + & + \\
\hline \multirow{3}{*}{ 全 } & health security & credence & 0 & +++ & + & + \\
\hline & pro-health features & search & +++ & + & 0 & 0 \\
\hline & production method & credence & 0 & +++ & 0 & 0 \\
\hline \multirow{2}{*}{ 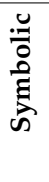 } & indication of place of & credence & 0 & 0 & +++ & +++ \\
\hline & brand & search & $\begin{array}{l}\text { probable } \\
\text { creation }\end{array}$ & $\begin{array}{l}\text { not justified } \\
\text { creation }\end{array}$ & $\begin{array}{l}\text { possible } \\
\text { creation }\end{array}$ & $\begin{array}{l}\text { highly } \\
\text { probable } \\
\text { creation }\end{array}$ \\
\hline \multirow{4}{*}{ 常 } & durability (shelf life) & search/experience & +++ & ++ & ++ & ++ \\
\hline & quality stability & search/experience & + & +++ & ++ & ++ \\
\hline & convenience ${ }^{*}$ & search & 0 & 0 & ++ & +++ \\
\hline & $\begin{array}{l}\text { complaints, } \\
\text { guarantees etc. }\end{array}$ & $\begin{array}{l}\text { search/ } \\
\text { xperience }\end{array}$ & 0 & 0 & + & +++ \\
\hline
\end{tabular}

* Convenience to buy, convenience to transport, convenience to eat, convenience to prepare or to process; 0 denotes marginal or none; + weak; ++ medium; +++ strong influence and responsibility; Source: own elaboration.

Growers (non-members in particular) selling apples to POs (or other intermediaries with the infrastructure needed to sort the apples) often face the problem of unfair quality assessment results for the fruit they deliver. The producer organisation (or another intermediary) will accept the product for grading and will then inform the fruit grower of the proportion of the delivery that has been classified as a dessert apple or an apple for processing. The process is opaque and the producer is usually forced to accept this verdict because the withdrawal of the apples after grading can be cumbersome due to the costs incurred for sorting, reloading, possible damage to the apples that occurred during the process, etc. The producer is thus exposed to the risk of receiving an unfair lower price for apples for processing, although in reality the product he delivered met the higher quality criteria.

POs and bigger individual producers deliver apples directly to retail chains-discount stores, supermarkets and hypermarkets. Retailers act as gatekeepers to the majority of consumers by controlling access to consumers as well as to information regarding their preference and purchasing behaviour [77]. Some experts point out that the emergence of large retailers on the Polish market in the mid-1990s entailed the modernisation of commercial practices applied by domestic producers, specifically related to logistics and improvement of product quality. Retail chains tried to act as chain masters-they introduced private standards, often stricter than the mandatory legal requirements, forcing producers to take appropriate measures to ensure a certain level of apple safety and quality. At present, although retailers declare implementation of high quality standards regarding fresh produce, 
the real picture is quite the opposite. Consumers are generally dissatisfied with the quality of apples sold in large retail chains, and random fruit quality checks carried out by the public agencies show that the quality of the fruit offered in retail chains does not even meet the mandatory requirements [78]. This situation can be explained as follows.

On the one hand, the apples are perishable and due to careless handling by the store staff, wrong temperature, or even picking over by customers can be easily damaged. This encourages large retailers to look for apples with a long shelf life (mainly determined by the cultivar, time of harvest and appropriate cooling) and not very susceptible to damage (usually determined by their hardness). Therefore, from the point of view of retail chains, the key features in assessing the quality of apples are somewhat different from those of the consumer. More importantly, in combination with the policy of large retailers focused on low purchase price, this may lead to a situation where a product of a lower quality than that desired by the consumer is placed on the shelf. Moreover, the low-price sourcing policy, dominant among large retailers, may encourage merchandisers to lower formal quality requirements. As a result, suppliers of large retail chains have no incentive to invest in the quality of the products sold through this channel.

As regards exporters, especially when the product is shipped to distant foreign markets, ensuring long shelf life of the product may be challenging. As in the case of retail chains, durability and vulnerability are important features sought by exporters, mainly due to long transport distances. However, particular varieties are even more important, due to specific needs of foreign markets. Apples are usually exported by POs, as well as by companies acting as intermediaries between POs or large fruit growers and a foreign buyer. Yet, the approach to shaping product quality for export markets is different from that of trading with supermarkets. It should be stressed at this point that among the current export destinations for apples from Poland, the markets that are demanding in terms of high quality prevail. An important incentive to ensure the premium quality are the high prices for dessert apples received abroad, which significantly exceed the level of prices received at home. Another factor is also the existence of strict controls, which are carried out by exporters, importers and public agencies responsible for quality inspections.

\section{Discussion}

The value chain approach shed some new light on the challenges faced by Polish apple growers. Due to the McKinsey business system and Porter's concept we understand the sources of competitive advantage both as the results of the way any particular activity is conducted, as well as in the broader context-as stemming from the interconnection between them $[1,12,14]$. Thus, the improvement of the position of Polish farmers depends not only on their efforts but also on the inter-organisational context within the whole value chain.

Such a systemic view is also reinforced by the development of the supply chain idea of integrated governance of the activities of its links [15-22]. Chains are defined not only by the flow of the products, but also by the informational interconnections. An apple has a complex of attributes, many of which are experience and credence in nature. Consequently, the perfect definition of an apple's attributes at any stage of the value chain is prohibitively costly ex ante. In a world populated by a non-trivial number of opportunistic agents, who are difficult to recognise in advance, this creates risk for transactions. Both sides of the transfer of any good make efforts to determine what the valuable attributes of the good are. But in the case of non-perfectly defined products they never will be fully successful in such attempts. Thus, both sides are exposed to the risk of a partner's endeavours to capture value hidden in those attributes of a good, which remain poorly delineated [79]. Therefore, the aim of integrated governance of the chain is not so easy to implement. There are some benefits from cooperation, while there are still possible temptations to defect and capture the wealth hidden in the not-perfectly-delineated attributes of transferred goods.

The above-mentioned problems are particularly serious in developing countries—often plagued by institutional voids, deficiencies in infrastructure and resources, and limited access to attractive 
markets [33]. One could doubt whether Poland falls into the developing countries category. In fact, this country experienced exceptional growth and development during the post-socialist transition. As a result, GDP per capita has more than tripled in this century (from 4.5 in 2000 to 15.4 thousand dollars in 2018), which means $4.5 \%$ yearly growth on average. However, Poland is still classified as one of the "emerging and developing economies" according to the International Monetary Fund. Indeed, it is more developed than many poor African or Asian countries according to the institutional matrix, infrastructure, and access to production factors. Nevertheless, some important constraints still exist. Probably better than the over-simplistic bipolar categorization of developed and developing countries could, in this case, be the proposition of Wallerstein's [2] world-systems theory with its core (where innovations are created and high-value added goods are produced), periphery (which are sources of raw materials and reservoirs of cheap labour force) and semi-periphery (which can mediate between the core and the periphery). As Poland belongs to the middle-income countries, and given its location and EU membership, it could be seen as a semi-periphery country.

However, this point of view represents a general outlook. From a particular point of view, the Polish apple sector does not keep on top of the problem. Poland's position against the global apple value chain is rather typical for peripheral countries (price competition, undifferentiated products). This is evidenced by the very low average price of apples obtained in Polish export $(0.43 \mathrm{USD} / \mathrm{kg})$ compared with the world average $(0.84 \mathrm{USD} / \mathrm{kg})$, which is related to the dominant importance of AJC in Polish export, which in turn is produced mainly from low-quality apples [60].

This could be interpreted as a kind of trap for Polish fruit growers-they are stuck in their position as cheap suppliers of the global value chain, while the basis for their advantage, i.e., low costs of labour, is shrinking as a result of dynamic economic growth of the country. Apple production is labour-intensive and fruit growers are experiencing serious problems with securing the workers, who are almost exclusively immigrants from Ukraine. Recently, the situation has become even more severe due to the SARS-CoV-2 pandemic and restrictions on crossing borders. The passage of time may only exacerbate the problem, while countries like Ukraine, Russia, Moldova, which are willing to take positions in the low-end apples segment, are maturing. While being a large, growing and export-oriented producer, Poland is threatened by loss of competitiveness in the global value chain. Such a picture fits well with the term of "immiserising growth" used by Kaplinsky ([13], p. 120), one of the prominent pioneers of the Global Value Chain.

The GVC concept represents practical orientation on strategies for supporting the development by upgrading the position of players in the chain. Generally, to increase the incomes of growers, they have to either enhance the skills content of processes conducted or move into more attractive market segments, which are somehow insulated from pressures of the "race to the bottom" through price competition. In particular, upgrading strategies in the GVC literature are typically classified as:

- process upgrading: conducting processes more efficiently by reorganising the activities or by superior technology,

- product upgrading: by moving into more value-added products by improving the old or by introducing new ones,

- intra-chain or functional upgrading: by acquiring new functions or by abandoning existing ones; such a change in the mix of activities aims at increasing the skill content of the more complex processes,

- inter-chain or inter-sectoral upgrading: through a lateral move; applying skills acquired in a particular function of a chain to move into a new sector/chain, which is more promising for the future $[11,32,80-83]$.

Trienekens [33] extended this typology. He proposed: upgrading of value-added production (which covers all the classical types mentioned above), value chain upgrading (achieving access to the right market and being a part of a relevant market channel) and upgrading of governance form (choosing the right coordination form within the value chain). In our opinion, apple growers should 
firstly try to follow this second path (product upgrading). The strongest players from system A should try upgrading into system $B$, while players from system $B$ should aim at inserting themselves into the global value chain, though not with AJC produce but with high-end dessert apples.

However, to follow that advice, serious constraints have to be overcome in the first place (compare with Figure 1). In our opinion, one of the most important of them is the barrier which Trienekens [33] called market access and market orientation. As we explain in the empirical part of the paper, the upstream transmission of customer needs and expectations within the apple value chain in Poland fails due to the lack of orchestrating incentives and chain member behaviour regarding quality issues (Figure 4). When differences in quality exist that are difficult to verify in advance, an incentive occurs to deliver low-quality products ('lemons') to the market. As a result, customers presuppose the risk of buying a 'lemon', which leads to a price reduction. It is difficult for the supplier of a high-quality good to convince the buyer that just his particular product is of high quality. As a consequence, the seller will either accept the inadequate (too low) price or refrain from selling at all. Therefore, market relations involving information asymmetry are plagued by adverse selection due to lack of incentives for suppliers to invest in quality and reluctance of many of them (sellers offering lemons) to reveal the true attributes of the product [84]. Relations between seller and buyer contain both cooperative as well as antagonistic and competitive aspects, while neither party has control over all variables characterizing this relationship (compare differences of influence and possible efforts towards quality within the value chain-Table 1). Hence, there is a space for discretionary behaviour of each party and the situation is somehow similar to employment relationships (compare [85]). Let us assume that in the case of the seller, the scope of his discretionary behaviour is determined by the $E_{\min }$ and $E_{\text {max }}$ points denoting, respectively, minimum and maximum effort toward producing or maintaining apple quality. Similarly, in the case of the buyer, we can point to $T_{\min }$ and $T_{\max }$, which mean price and other important criteria for the seller's conditions of trade-respectively at the minimum level (at which exchange with the seller can still be retained regarding his best alternative available) and at the maximum level (not yet undermining the financial condition of the buyer's business)-Figure 5.

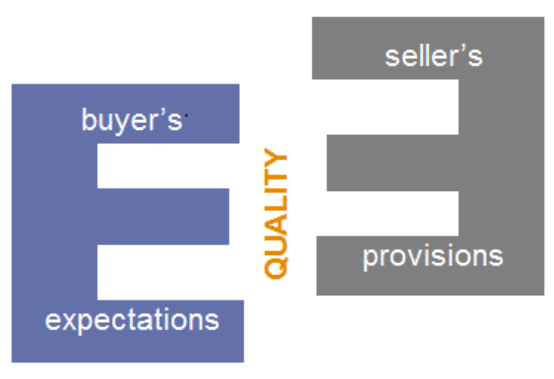

(a) Good quality

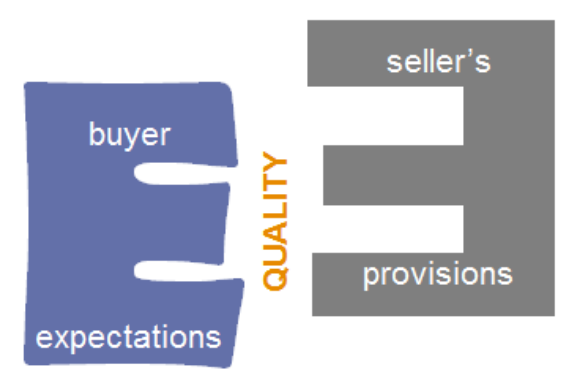

(b) Poor quality

Figure 4. Good and poor quality according to the ZIP model; Source: own elaboration based on [86] cited by [87], p. 29.

The combination of competition and cooperation aspects suggests that the outlined situation can be described using the prisoner's dilemma model [88]. By focusing on the antagonistic aspect of relationships, each party can strive to maximise its own benefits, regardless of the interests of the other party (defection, opportunism). Such behaviours represent the expectation of obtaining a "payoff of temptation" not counting on the fact that it is accompanied by a "sucker's payoff" for the partner of the transaction $[89,90]$. Such a "hit and run" strategy could be sometimes successful but only initially. The clue of the prisoner's dilemma means that-if both sides act as maximisers of individual utility-they both receive a "non-cooperative payoff", a kind of punishment for opportunism: $E_{\text {min }}-T_{\text {min }}[88,90]$. 


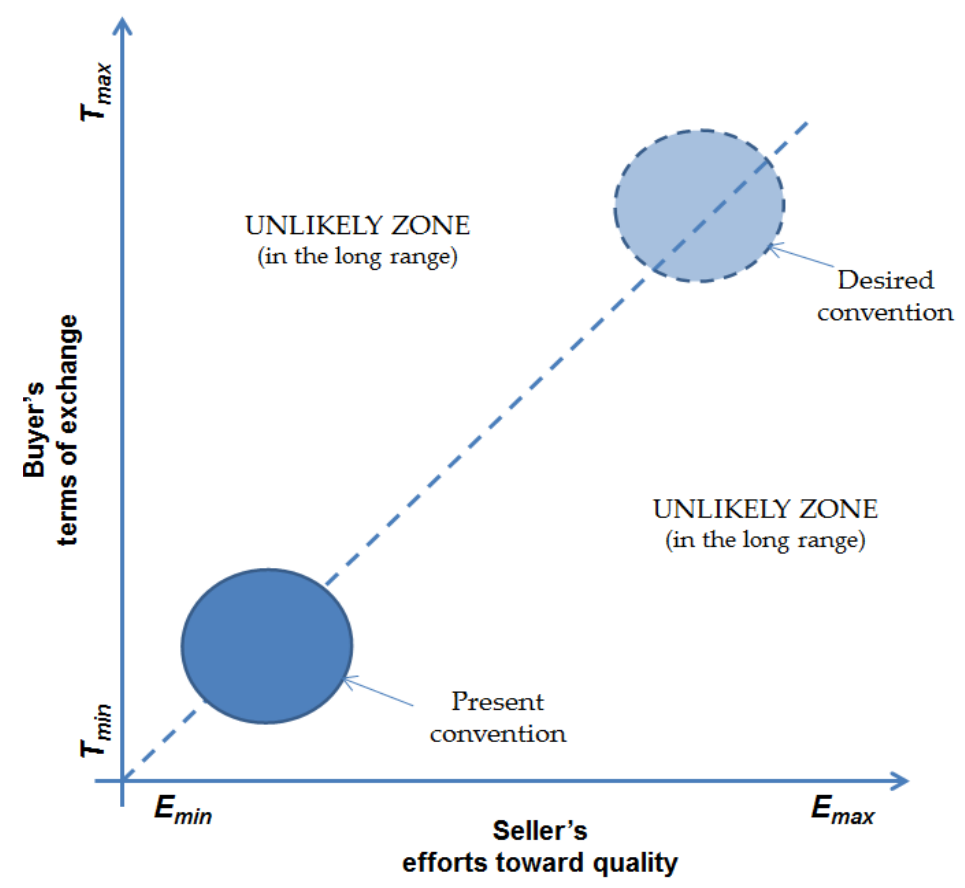

Figure 5. Possible relation between a grower's efforts toward apple quality and received from intermediary terms of exchange; Source: own elaboration based on an idea drawn from [85] (p. 835).

There are, however, two strategies to avoid the trap of a prisoner's dilemma: establishing lasting long-term relationships and changing the structure of payoffs in the game through contracts [89,91]. This idea is in line with the results obtained in the luxury industry by Caniato et al. [85]. They found a tight form of cooperation between chain agents. In fact, value chains orchestrated by high-quality standards are often found in the fashion and luxury industries. However, also in agri-business, "several groups of high-quality food products such as wine, coffee, spirits and cheese seem to have very similar supply chains" ([41], p. 132). However, the position of any kind of food is on the spectrum between extremes, the high-commodity specification of a product is not fixed forever. According to Carvalho et al., "traditionally coffee has been traded as a commodity, only more recently, new alternative schemes to trade coffee emerged" ([41], p. 133). As evidenced by Oliveira et al., the transition toward higher quality coffee production in Brazil was possible due to changes in the way the value chain's interrelations among agents are governed, because "coffee quality strongly stems from coordination features, not only technical aspects" ([92], p. 789).

Typically, there are established conventions (circles in Figure 5) that determine both the level of effort $E$, as well as the offered trade conditions $T$. Conventions are shaped as a result of the routine of regularly repeated behaviour and the application of sanctions against behaviour deviating from the convention- "effort conventions are based on history, sanctions and observation of average effort standards" ([88], p. 835). From this perspective, we can treat the present situation in the apple chain in Poland as a path-dependent solution based on history and experience learned from relations within the value chain, which evolved in a rather antagonistic manner.

Thus, the issue of upgrading the position of apple growers in the chain should focus on more cooperative ways of doing business [93], which in turn will allow information asymmetries to be overcome. As we mentioned above, one of the basic forms of strengthening position in the value chain is product upgrading. However, many crucial quality attributes of apples are related to experience and credence. In such cases, the problem is how to create incentives for players within the value chain to make efforts towards quality even though information asymmetry combined with self-interest creates incentives to do just the opposite [46]. 
According to Akerlof [84], there are mechanisms that may arise in such cases which can help to cope with such asymmetries: guarantees, brand names, standardization and licensing/certification. In our opinion, the development of such mechanisms is a promising direction for Polish apple growers. This will be conditional on upgrading through gaining market orientation and translating it into improved products and access to better markets. Particularly, club brands as well as Protected Denominations of Origin (PDO) and Protected Geographical Indications (PGI) should be considered more carefully as possible methods. As Raynaud et al. [94] evidenced, private brands as well as PDO and PGI could be promising quality labelling strategies in the agri-food vertical chains.

\section{Conclusions}

Globalisation has made substantial shifts in the worldwide division of labour and reshaped the global organisation of production. This new organisation often takes the form of the chain connecting vertically related actors, particularly in the agri-food production systems. Such a form of global inter-firm connectedness challenges the traditional way of measuring countries' international competitiveness. At first glance, Poland seems to be a very competitive apple producer worldwide. However, looking through the lens of world-systems theory and the Global Value Chain framework, one could observe that Polish apple growers are experiencing a very weak position in the GVC, as evidenced by their share in the value added (as measured by prices) despite their huge potential (as measured by volumes) and despite the commodity's long-term growth.

Globalisation has been associated with increasing polarisation and inequalities. Failures of producers and even whole national sectors to insert themselves properly into the GVC could result in the so-called immiserising growth. This is a serious challenge for Polish apple growers as well as for many farmers around the world. We used an eclectic approach of GVC (drawing on both business-management and socio-economic strands of literature) as a framework to investigate the challenge of downgrading risk for farmers.

As an empirical illustration, we investigated the Polish apple sector-the third largest apple producer and the second largest apple juice concentrate exporter in the world. Despite the sector's export orientation and its strong connection to the global value chain, Polish growers' slice of the "value pie" is very unsatisfactory, even by the standards of a semi-peripheral country. We found that the root-cause problems are quality issues. Responsibility for the final quality offered for the end-user is strongly dispersed across many actors in the chain, while interrelations between them are plagued by the information asymmetry problem. Thus, the upstream transmission of end-user quality expectations within the apple value chain fails due to the lack of orchestrating incentives, and causes misbehaviour against quality at different stages of the chain. Therefore, efforts for upgrading the position of Polish apple growers in the GVC should focus on overcoming information asymmetries. Mechanisms such as branding, standardisation, and certification could be promising. The results of the study cannot be generalised to all agri-food chains. However, we believe that our approach is not too specific to apples and can be used for other products that can be differentiated, particularly products sold fresh to consumers (e.g., other fruits, vegetables, meat, fish).

The limitation of this study is its explorative character. Thus, the empirical part of the paper has a mainly qualitative and descriptive nature. However, in our opinion, it is justifiable at this stage of our preliminary research. To the best of our knowledge, this paper represents the first attempt to describe the apple sector in Poland and to explain its conduct based on the GVC framework. The desired direction of future research will be more quantitatively oriented studies. Particularly, a detailed investigation of value-added distribution could give valuable insights. Following our recommendation of branding and certification, one could study more deeply issues such as club varieties and relevant brands, as well as Protected Denominations of Origin and Protected Geographical Indications. Last but not least, issues regarding the modes of governance used within the apple value chain and its institutional environment also seem to be very promising directions for future research. 
Author Contributions: Conceptualization, M.P. and A.C.; methodology, M.P. and A.C.; investigation, M.P., A.C., P.K., A.M.-R.; resources, M.P., A.C., P.K., A.M.-R.; data curation, M.P., A.C., P.K.; writing—original draft preparation, M.P., A.C., P.K., A.M.-R.; writing-review and editing M.P., A.C., P.K., A.M.-R.; funding acquisition, A.M.-R. All authors have read and agreed to the published version of the manuscript.

Funding: This research received no external funding; publication was financed by Warsaw University of Life Sciences -SGGW. The funders had no role in the design of the study; in the collection, analyses, or interpretation of data; in the writing of the manuscript, or in the decision to publish the results.

Conflicts of Interest: The authors declare no conflict of interest.

\section{References}

1. Porter, M.E. Competitive Advantage. Creating and Sustaining Superior Performance; The Free Press: New York, NY, USA, 1998; ISBN 0-684-84146-0.

2. Wallerstein, I. The Modern World-System I. In Capitalist Agriculture and the Origins of the European World-Economy in the Sixteen Century; Academic Press: New York, NY, USA, 1974; ISBN 978-0-520-26757-2.

3. Hopkins, T.K.; Wallerstein, I. Commodity Chains in the World Economy Prior to 1800. Review 1986, 10, 157-170.

4. Hopkins, T.K.; Wallerstein, I. Commodity Chains: Construct and research. In Commodity Chains and Global Capitalism; Gereffi, G., Korzeniewicz, M., Eds.; Praeger Publishers: Westport, CT, USA, 1994; ISBN 0-275-94573-1.

5. Ruben, R.; van Boekel, M.A.J.S.; van Tilburg, A.; Trienekens, J.H. (Eds.) Tropical Food Chains: Governance Regimes for Quality Management; Wageningen Academic Publishers: Wageningen, NL, USA, 2007; ISBN 9789086860272.

6. World Bank. The Dynamics of Vertical Co-Ordination in Agro-Food Chains in Europe and Central Asia; The World Bank: Washington, DC, USA, 2005.

7. Swinnen Johan, F.M. (Ed.) The dynamics of vertical coordination in agri-food supply chains in transition countries. In Global Supply Chains, Standards and the Poor; CABI: Oxon, UK, 2007; pp. 42-58.

8. Csaki, C.; Forgacs, C.; Milczarek-Andrzejewska, D.; Wilkin, J. Restructuring Market. Relations in Food and Agriculture in Central and Eastern Europe: Impacts upon Small Farmers; Agroinform: Budapest, Hungary, 2008.

9. Malak-Rawlikowska, A.; Milczarek-Andrzejewska, D.; Fałkowski, J. Farmers' Bargaining Power and Input Prices: What Can We Learn from Self-Reported Assessments? Soc. Sci. 2019, 8, 63. [CrossRef]

10. Fałkowski, J.; Malak-Rawlikowska, A.; Milczarek-Andrzejewska, D. Farmers' self-reported bargaining power and price heterogeneity: Evidence from the dairy supply chain. Br. Food J. 2017, 119, 1672-1686. [CrossRef]

11. Gereffi, G.; Fernandez-Stark, K. Global Value Chain Analysis: A Primer; Center on Globalization, Governance \& Competitiveness (CGGC), Duke University: Durham, NC, USA, 2011.

12. Enduring Ideas: The Business System. McKinsey Quarterly, 1 June 2009. Available online: https://www.mckinsey.com/business-functions/strategy-and-corporate-finance/our-insights/enduringideas-the-business-system (accessed on 12 January 2020).

13. Kaplinsky, R. Globalisation and unequalisation: What can be learned from value chain analysis? J. Dev. Stud. 2000, 37, 117-146. [CrossRef]

14. Gluck, F.W. Strategic Choices and Research Allocation. McKinsey Q. 1980, 1, 22-33.

15. Camps, T. Chains and Networks: Theory and Practice. In The Emerging World of Chains and Networks. Bridging Theory and Practice; Camps, T., Diederen, P., Hofstede, G.J., Vos, B., Eds.; Reed Business Information: Den Haag, The Netherlands, 2004; ISBN 9789059019287.

16. Coyle, J.J.; Bardi, E.J.; Langley, C.J. Management of Business Logistics: A Supply Chain Perspective, 7th ed.; South-Western College: Cincinnati, OH, USA, 2002; ISBN 978-0324007510.

17. Sweeney, E. Towards a Unified Definition of Supply Chain Management. Int. J. Appl. Logist. 2011, 2/3, 30-48. [CrossRef]

18. Lazzarini, S.G.; Chaddd, F.R.; Cook, M.L. Integrating supply chain and network analyses: The study of net chains. J. Chain Netw. Sci. 2001, 1, 7-22. [CrossRef]

19. van der Vorst, J.G.A.J. Supply Chain Management: Theory and Practices. In The Emerging World of Chains and Networks. Bridging Theory and Practice; Camps, T., Diederen, P., Hofstede, G.J., Vos, B., Eds.; Reed Business Information: Den Haag, The Netherlands, 2004; ISBN 9789059019287.

20. Christopher, M. Logistics and Supply Chain Management: Creating Value-Adding Networks, 4th ed.; Financial Times Press, Prentice Hall: Harlow, UK, 2011; ISBN 978-0273731122. 
21. Storey, J.; Emberson, C.; Godsell, J.; Harrison, A. Supply chain management: Theory, practice and future challenge. Int. J. Oper. Prod. Manag. 2006, 26, 754-774. [CrossRef]

22. Oliver, R.K.; Webber, M.D. Supply chain management: Logistics catches up with strategy. In Logistics: The Strategic Issues; Christopher, M., Ed.; Chapman and Hall: London, UK, 1982; pp. 63-75. ISBN 978-0412415500.

23. Bernstein, H. The political economy of the maize filière. J. Peasant Stud. 1996, 23, 120-145. [CrossRef]

24. Raikes, P.; Jensen, M.F.; Ponte, S. Global Commodity Chain Analysis and the French Filière Approach: Comparison and Critique. Econ. Soc. 2000, 29, 390-417. [CrossRef]

25. Temple, L.; Lançon, F.; Palpacuer, F.; Paché, G. Actualisation du concept de filière dans l'agriculture et l'agroalimentaire. AG 2011, 33, 1785-1797.

26. Braudel, F. La Dynamique du Capiatlisme; Éditions Flammarion: Paris, France, 2018; ISBN 978-2081428430.

27. Hopkins, T.K.; Wallerstein, I. Patterns of development of the modern word-system. Review 1977, 1, 111-145. [CrossRef]

28. Bair, J. Editor's Introduction: Commodity Chains in and of the World-Systems. J. World Syst. Res. 2014, 20, 1-10. [CrossRef]

29. Gereffi, G. International Trade and Industrial Upgrading in the Apparel Commodity Chain. J. Int. Econ. 1999, 48, 37-70. [CrossRef]

30. Drost, S.; van Wijk, J.; Vellema, S. Development Value Chains Meet Business Supply Chains: The Concept of Global Value Chains Unraveled; Working Paper: No. 2; The Partnerships Resource Centre: Rotterdam, The Netherlands, 2010.

31. Sturgeon, T.J. From Commodity Chains to Value Chains: Interdisciplinary Theory Building in an Age of Globalization; Working Paper Series, MIT-IPC-08-001; Industrial Performance Center; Massachusetts Institute of Technology: Cambridge, MA, USA, 2008.

32. Gereffi, G.; Humphrey, J.; Kaplinsky, R.; Sturgeon, T.J. Introduction: Globalisation, Value Chains and Development. IDS Bull. 2001, 32, 1-8. [CrossRef]

33. Trienekens, J.H. Agricultural Value Chains in Developing Countries A Framework for Analysis. Int. Food Agribus. Manag. Rev. 2011, 14, 51-82. [CrossRef]

34. Grunert, K.; Fruensgaard, J.; Risom, L.; Jespersen, K.; Sonne, A. Market orientation of value chains; a conceptual framework based on four case studies from the food industry. Eur. J. Mark. 2005, 39, 429-455. [CrossRef]

35. Baker, T.L.; Simpson, P.M.; Siguaw, J.A. The impact of supplier's perceptions of reseller market orientation on key relationship constructs. J. Acad. Mark. Sci. 1999, 27, 50-57. [CrossRef]

36. Elg, U. Inter-firm Market Orientation: Its Significance and Antecedents in Distribution Networks. J. Mark. Manag. 2002, 18, 633-656. [CrossRef]

37. Elg, U. Market orientation processes in retailing: A cross-national study. Eur. J. Mark. 2007, 41, 568-589. [CrossRef]

38. Grunert, K.G.; Jeppesen, L.F.; Sonne, A.M.; Hansen, K.; Trondsen, T. Market orientation at industry and value chain levels: Concepts, determinants and consequences. J. Cust. 2002, 1, 167-194. [CrossRef]

39. Siguaw, J.A.; Simpson, P.M.; Thomas, L.; Baker, T.L. Effects of Supplier Market Orientation on Distributor Market Orientation and the Channel Relationship: The Distributor Perspective. J. Mark. 1998, 62, 99-111. [CrossRef]

40. Simpson, P.; Siguaw, J.; Baker, T.L. A model of value creation: Supplier behaviors and their impact on reseller-perceive d value. Ind. Mark. Manag. 2001, 30, 119-134. [CrossRef]

41. Carhalho, J.M.; Paiva, E.L.; Vieira, L.M. Quality attributes of a high specification product. Evidences from the speciality cofee business. Br. Food J. 2016, 118, 132-149. [CrossRef]

42. Grunert, K.G. How changes in consumer behaviour and retailing affect competence requirements for food producers and processors. Econ. Agrar. Recur. Nat. 2006, 6, 3-22. [CrossRef]

43. Stiglitz, J. The Contributions of the Economics of Information to Twentieth Century Economics. Q. J. Econ. 2000, 115, 1441-1478. [CrossRef]

44. Williamson, O.E. The Economic Institutions of Capitalism. Firms, Markets, Relational Contracting; The Free Press: New York, NY, USA, 1985; ISBN 0-68-486374-X.

45. Nelson, P. Information and Consumer Behavior. J. Polit. Econ. 1970, 78, 311-329. [CrossRef]

46. Tirole, J. The Theory of Industrial Organization; The MIT Press: Cambridge, MA, USA, 1988; ISBN 978-0-262-20071-4. 
47. Darby, M.R.; Karni, E. Free Competition and the Optimal Amount of Fraud. J. Law Econ. 1973, 16, 67-88. [CrossRef]

48. Ahmed, R.A.; El-Shehawy, M.; Lutang, L. The Structure and Competitiveness of China's Apple Exports. World J. Agric. Sci. 2011, 7, 678-683.

49. FAO. Database. Available online: http://www.fao.org/faostat/en/\#data/FBS (accessed on 10 February 2020).

50. USDA. Fresh Apples, Grapes, and Pears: World Markets and Trade. 2019. Available online: https: //apps.fas.usda.gov/psdonline/circulars/fruit.pdf (accessed on 20 April 2020).

51. Klepacka, A.M.; Florkowski, W.J. Poland's apple sector and the embargo on fruit exports to Russia. Acta Hortic. 2016, 1132, 31-38. [CrossRef]

52. Nosecka, B.; Bugała, A. Rynek Jabłek w Polsce. Available online: http://www.agroindustry.pl/index.php/ 2019/04/29/rynek-jablek-w-polsce/ (accessed on 28 March 2020).

53. GUS. Produkcja Upraw Rolnych i Ogrodniczych w 2018 Roku. Available online: https: //stat.gov.pl/obszary-tematyczne/rolnictwo-lesnictwo/uprawy-rolne-i-ogrodnicze/produkcja-uprawrolnych-iogrodniczych-w-2018-roku,9,17.html (accessed on 1 March 2020).

54. World Apple and Pear Association. European Apple and Pear Crop Forecast. 2018. Available online: https: //prognosfruit.eu/wp-content/uploads/2018/08/European-Apple-Pear-Crop-Forecast-FINAL.pdf (accessed on 20 April 2020).

55. Fałkowski, J.; Chlebicka, A. Fruit and Vegetables Producer Organisations-Some Insights on Their Functioning Based on Data from Poland; Joint Research Centre, European Commission: Luxembourg, 2018. [CrossRef]

56. Amat, L.; Chlebicka, A.; Ferreira, I.; Montanari, F.; Sorrentino, A.; Szabo, G.G.; Traon, D.; Russo, C. Study of the Best Ways for Producer Organisations to be Formed, Carry out Their Activities and be Supported: Final Report; OPL: Luxembourg, 2019; ISBN 978-927-998-775-5.

57. GfK Polonia. Sieci Detaliczne na Rynku FMCG w Polsce 2016; GfK Polonia: Warszawa, Poland, 2017.

58. Jąder, K. Konsumpcja owoców w Polsce w różnych typach gospodarstw domowych. Rocz. Naukowe Stow. Ekonom. Rol. Agrobiz. 2016, 18, 117-123.

59. Kraciński, P. Polski eksport jabłek na tle światowego handlu jabłkami. Rocz. Naukowe Stow. Ekonom. Rol. Agrobiz. 2014, XVI, 159-164.

60. Kraciński, P. Pozycja Konkurencyjna Jabłek i Zagęszczonego Soku Jabłkowego na Rynkach Zagranicznych. 2019. Available online: https://sgw0.bg.sggw.pl/exlibris/aleph/a22_1/apache_media/ D537P4TRFT6KLDJCMKQFX6KD7SCHGY.pdf (accessed on 1 February 2020).

61. Kacprzak, T.; Himstedt, K. The Influence of the Russian Embargo on the Economic Situation of Apple Producers in the Eastern Part of the Masovia Province. Probl. World Agric. 2019, 19, 54-64. [CrossRef]

62. Caswell, J.A.; Noelke, C.M.; Mojduszka, E.M. Unifying Two Frameworks for Analyzing Quality and Quality Assurance for Food Products. In Global Food Trade and Consumer Demand for Quality; Krissoff, B., Bohman, M., Caswell, J.A., Eds.; Kluwer Academic/Plenum Publishers: New York, NY, USA, 2002; pp. 43-61.

63. Gao, S.S.; Wong, L.A.; Spreen, T.H. French consumer perception, preference of, and willingness to pay for fresh fruit based on country of origin. Br. Food J. 2014, 116, 805-820. [CrossRef]

64. Alphonce, R.; Temu, A.; Almli, V.L. European consumer preference for African dried fruits. Br. Food J. 2015, 117, 1886-1902. [CrossRef]

65. Jiménez-Guerrero, J.F.; Gázquez-Abad, J.C.; Huertas-García, R.; Mondéjar-Jiménez, J.A. Estimating consumer preferences for extrinsic and intrinsic attributes of vegetables. A study of German consumers. Span. J. Agric. Res. 2012, 10, 539-551. [CrossRef]

66. Manalo, A.B. Assessing the Importance of Apple Attributes: An Agricultural Application of Conjoint Analysis. Northeast. J. Agric. Resour. Econ. 1990, 19, 118-124. [CrossRef]

67. Bonany, J.; Buehler, A.; Carbó, J.; Codarin, S.; Donati, F.; Echeverria, G.; Egger, S.; Guerra, W.; Hilaire, C.; Höller, I.; et al. Consumer eating quality acceptance of new apple varieties in different European countries. Food Qual. Prefer. 2013, 30, 250-259. [CrossRef]

68. Gunden, C.; Thomas, T. Assessing consumer attitudes towards fresh fruit and vegetable attributes. J. Food Agric. Environ. 2012, 10, 85-88.

69. Denver, S.; Jensen, J.D. Consumer preferences for organically and locally produced apples. Food Qual. Prefer. 2014, 31, 129-134. [CrossRef]

70. Verain, M.C.D.; Sijtsema, S.J.; Antonides, A. Consumer segmentation based on food category attribute importance: The relation with healthiness and sustainability perceptions. Food Qual. Prefer. 2016, 48, 99-106. 
71. Noelke, C.M.; Caswell, J.A. A Model of The Implementation of Quality Management Systems for Credence Attributes. In Proceedings of the Annual Meeting, Tampa, FL, USA, 30 July-2 August 2000; American Agricultural Economics Association (New Name 2008: Agricultural and Applied Economics Association): St. Paul, MN, USA, 2000. [CrossRef]

72. Poole, N.D.; Martínez, L.; Giménez, V.F. Quality perceptions under evolving information conditions: Implications for diet, health and consumer satisfaction. Food Policy 2007, 32, 175-188. [CrossRef]

73. Moser, R.; Raffaelli, R. Consumer preferences for sustainable production methods in apple purchasing behaviour: A non-hypothetical choice experiment. Int. J. Consum. Stud. 2012, 36, 141-148. [CrossRef]

74. Badar, H.; Ariyawardana, A.; Collins, R. Capturing consumer preferences for value chain improvements in the mango industry of Pakistan. Int. Food Agribus. Manag. Rev. 2015, 18, 131-148.

75. Sexton, R. Market power, misconceptions, and modern agricultural markets. Am. J. Agric. Econ. 2013, 95, 209-219. [CrossRef]

76. Starbird, S.A.; Amanor-Boadu, A. Contract selectivity, food safety, and traceability. J. Agric. Food Ind. Organ. 2007, 5, 1-22. [CrossRef]

77. Nordås, H.K. Gatekeepers to consumer markets: The role of retailers in international trade. Int. Rev. Retail. Distrib. Consum. Res. 2008, 18, 449-472. [CrossRef]

78. GIJHARS. Sprawozdanie Roczne 2018; GIJHARS: Warszawa, Poland, 2019. Available online: https://www.gov. pl/web/ijhars/sprawozdanie-roczne (accessed on 21 March 2020).

79. Barzel, Y. Economic Analysis of Property Rights, 2nd ed.; Cambridge University Press: New York, NY, USA, 2009; ISBN 978-0-521-59713-5.

80. Gereffi, G. Global value chains in a post-Washington Consensus world. Rev. Int. Polit. Econ. 2014, 21, 9-37.

81. Humphrey, J.; Schmitz, H. How does insertion in global value chains affect upgrading in industrial clusters? Reg. Stud. 2002, 36, 1017-1027. [CrossRef]

82. Kaplinsky, R.; Morris, M. A Handbook for Value Chain Research; Institute of Development Studies, University of Sussex: Brighton, UK, 2002.

83. Stamm, A. Value Chains for Development Policy. Challenges for Trade Policy and the Promotion of Economic Development; Deutsche Gesellschaft für Technische Zusammenarbeit: Eschborn, Germany, 2004.

84. Akerlof, G.A. The Market for 'Lemons': Quality Uncertainty and the Market Mechanism. Q. J. Econ. 1970, 84, 488-500. [CrossRef]

85. Caniato, F.; Caridi, M.; Castelli, C.M.; Golini, R. A contingency approach for S.C. management in the Italian luxury industy: Do consolidated model fit? Int. J. Prod. Econ. 2009, 120, 176-189. [CrossRef]

86. Berg, M.G.; van den Delsing, B.M.A. Kwaliteit van Levensmiddelen: Hoe te Bereiken? Samson: Alphen aan de Rijn, The Netherlands, 1999; ISBN 9789014061474.

87. Luning, P.A.; Marcelis, W.J.; Jongen, W.M.F. Food Quality Management: A Techno-Managerial Approach; Wageningen Pers: Wageningen, The Netherlands, 2002; ISBN 9789074134811.

88. Leibenstein, H. Property Rights and X-Efficiency: Comment. Am. Econ. Rev. 1983, 73, 831-842.

89. Axelrod, R. The Evolution of Cooperation, Revised ed.; Basic Books: Cambridge, MA, USA, 2006; ISBN 978-0-465-00564-2.

90. Straffin, P.D. Game Theory and Strategy; American Mathematical Society: Washington, DC, USA, 1993; ISBN 978-0883856376.

91. Kay, J. Foundations of Corporate Success: How Business Strategies Add Value; Oxford University Press: New York, NY, USA, 1993; ISBN 0-19-828781-X.

92. de Oliveira, G.M.; Zylbersztajn, D.; Saes, M.S.M. Can contracts substitute hierarchy? Evidence from high-quality coffee sector in Brazil. Br. Food J. 2019, 121, 787-802. [CrossRef]

93. Goodhue, R.E.; Heien, D.M.; Lee, H.; Sumner, D.A. Contracts and Quality in the California Winegrape Industry. Rev. Ind. Organ. 2003, 23, 267-282. [CrossRef]

94. Raynaud, E.; Sauvee, L.; Valceschini, E. Alignment between quality enforcement devices and governance structures in the agro-food vertical chains. J. Manag. Gov. 2005, 9, 47-77. [CrossRef]

(C) 2020 by the authors. Licensee MDPI, Basel, Switzerland. This article is an open access article distributed under the terms and conditions of the Creative Commons Attribution (CC BY) license (http://creativecommons.org/licenses/by/4.0/). 